\title{
Investment Rationale for Range Improvement Practices in Eastern Montana
}

\author{
JOHN R. LACEY, J. ROSS WIGHT, AND JOHN P. WORKMAN
}

\begin{abstract}
Evidence suggests that the range livestock industry in the Northern Great Plains is not as productive as it should be. Ranchers are not readily adopting the range improvement practices that researchers recommend. Therefore, an economic survey of eastern Montana ranchers was conducted to evaluate the current status of range improvement practices. Specific objectives were to determine:(1) if range improvement investments were influenced by ranch size; (2) the kinds of range improvements that were being implemented; (3) the areas where additional research was needed in range improvements; and (4) if stocking rates were influenced by ranch size.

It was determined that a majority of the ranchers had purchased equipment and invested in additional water developments, fencing, and other structural improvements during the previous five-year period. A much smaller percentage had invested in seeded pastures, contour furrows, fertilizer, and other nonstructural improvements. Although small ranches had more range improvements developed per unit area, large ranches (401 animal units or more) were investing in range improvements more frequently than smaller ranches. Questionnaires returned from 568 ranchers indicated that research on range improvement practices should emphasize range seeding. Stocking rate on rangeland was not influenced by ranch size.
\end{abstract}

Eastern Montana is an important livestock producing region. During a 1979 survey, 681,300 cattle, including calves, and 215,600 stock sheep and lambs, were counted in 14 eastern counties (Montana Dept. of Agr. 1980). Annual cash receipts from the sale of livestock and livest ock products totaled $\$ 200,745,700$. Studies evaluating range improvement practices have shown that a variety of different improvement practices can increase herbage production in eastern Montana (Black and Reitz 1969, Houston 1971, Wight 1975, Wight et al. 1978, Wight and White 1974). Such range improvement practices can substantially increase livestock production in eastern Montana (Houston and Urick 1972, Wight et al. 1978) and in other regions (Cook and Jefferies 1963, Kearl 1975, Kearl 1979, Workman and Hooper 1968).

Range improvements are "special treatments, developments, and structures used to improve range forage resources or to facilitate their use by grazing animals" (Valentine 1971). Although a wide selection of improvement practices exist, Wheeler (1970) determined that capital expenditures for range improvements in the northern Great Plains were largely limited to water development and fencing. A recent U.S. Forest Service study (Horvath et al. 1978), suggested that land management agencies have also invested most of their improvement funding on water development and fencing. Wheeler (1970) suspected that water and fencing were popular improvements because they allowed the rancher to immediately graze more livestock by improving distribution on the same land base. However, he cautioned that the practice of increasing livestock numbers to use the newly accessible portions of the range could lead to overstocking and be detrimental to the long-term productivity of an area.

Authors a re range extension specialist, Montana State University, Bozeman 59717, range scientist, USDA, ARS, 270 South Orchard, Boise, Idaho 83705; and professor, Department of Range Science, Utah State University, Logan 84322.

This article is a contribution from the Northwest Watershed Research Center, Agricultural Research Service, USDA; Bureau of Land Management, USDI; and Montana State University, Bozeman, in cooperation with the Agricultural Experiment Station, University of Idaho, Moscow 83843.

Manuscript accepted April 3, 1984.
Nonstructural kinds of range improvements, such as brush control, seeded pastures, and contour furrowing have not been as popular as fencing, water developments, and other structural improvements (Lacey 1981). Their economic benefits tend to be less obvious than those from structural improvements.

Although scientists develop and field test range improvement practices, it is the livestock producer who ultimately determines the number and kind of improvements on his ranch. Therefore, an economic survey of eastern Montana ranches was conducted to evaluate the current status of range improvement practices. Specific objectives were to determine: (1) if range improvement investments are dependent on ranch size; (2) the kinds of range improvements that are being implemented; (3) the needs (as perceived by the rancher) in the area of range improvement research; and (4) how the use of range improvement practices could influence stocking rate differences between ranch sizes.

To enhance communication between ranchers, agricultural lenders, and range scientists, these issues must be resolved. Better communication is needed among these facets of the range livestock industry to ensure long-term productivity.

\section{Methods}

Tax records were examined in 14 counties during July 1979 (Fig. 1). Names of all operators who paid taxes on more than 25 head of cattle and/or $\mathbf{5 0}$ sheep were recorded. The study area was separated into 8 northern and 6 southern counties where livestock production accounts for 39 and $80 \%$ of the total agricultural receipts, respectively. In the predominantly grain producing northern counties, the study sa mple was restricted to cattle operators who carried bet ween 50 and 150 animal units (AU). Ranches in the southern counties were less homogenous, and our sample included 3 ranch sizes (small, 50-200; medium, 201-400; and large, $401 \mathrm{AU}$ or more), 18 of which produced both cattle and sheep. For computation purposes, 5 sheep were the equivalent of an AU.

A two-phase sampling technique was used. First, a stratified random sampling scheme was used to obtain a proportionate number of names from the tax rolls within each group of ranches. A total of 1,253 ranches was selected and a standardized questionnaire was mailed to these operators during May, 1980. They were asked to return the questionnaire and indicate whether they would participate in a personal interview. A smaller sample of 117 ranchers (about 30 in each size class) was then selected from those willing to be interviewed, and this group was personally interviewed during July through September, 1980. Incomplete data or atypical operations made it necessary to exclude some of the personal interviews from the final analysis. Production and cost data for the small, medium, and large ranches in southeastern Montana are based on samples of 18,21 , and 30 ranches, respectively. Northeastern Montana ranchers were not included in the production and cost analyses because $61 \%$ of their agricultural receipts were from the production of grain.

Analysis of variance was used to determine if cost and production parameters (collected during personal interviews) varied significantly between small, medium, and large ranches in southeastern Montana. Chi-square contingency tables (Snedecor and Cochran 1967) were used to determine if a rancher's participation in the survey, his investment in improvement practices, and his research recommendations were related to ranch size. Differences among 
Table 1. Percent of eastem Montana ranchers investing in various improvement practices during the bast five years.'

\begin{tabular}{|c|c|c|c|c|c|}
\hline \multirow[b]{3}{*}{ Improvement practices } & \multicolumn{4}{|c|}{ Ranch size and location } & \multirow[b]{3}{*}{$\begin{array}{c}\text { Total } \\
\text { sample }\end{array}$} \\
\hline & \multirow{2}{*}{ 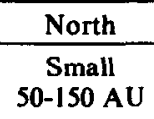 } & \multicolumn{3}{|c|}{ South } & \\
\hline & & $\begin{array}{c}\text { Small } \\
50-200 \mathrm{AU}\end{array}$ & $\begin{array}{c}\text { Medium } \\
201-400 \mathrm{AU}\end{array}$ & $\begin{array}{c}\text { Large } \\
>400 \mathrm{AU}\end{array}$ & \\
\hline $\begin{array}{l}\text { Purchase equipment } \\
\text { Water facilities } \\
\text { Breeding stock } \\
\text { Fencing } \\
\text { Improve hayland } \\
\text { Lease range } \\
\text { Seed pastures } \\
\text { Convert range to crop } \\
\text { Convert crop to range } \\
\text { Purchase range } \\
\text { Fertilize pasture } \\
\text { Contour furrow } \\
\text { Fertilize range }\end{array}$ & $\begin{array}{l}74 \mathrm{~A}^{2} \\
67 \mathrm{~A} \\
69 \mathrm{~A} \\
60 \mathrm{~A} \\
36 \mathrm{~A} \\
34 \mathrm{AB} \\
29 \mathrm{~A} \\
19 \mathrm{~A} \\
28 \mathrm{~A} \\
17 \mathrm{~A} \\
21 \mathrm{~A} \\
3 \mathrm{~A} \\
6 \mathrm{~A}\end{array}$ & $\begin{array}{l}76 \mathrm{AB} \\
63 \mathrm{~A} \\
68 \mathrm{~A} \\
56 \mathrm{~A} \\
40 \mathrm{~A} \\
25 \mathrm{~A} \\
27 \mathrm{~A} \\
27 \mathrm{AB} \\
22 \mathrm{AB} \\
16 \mathrm{~A} \\
14 \mathrm{~A} \\
3 \mathrm{~A} \\
5 \mathrm{~A}\end{array}$ & $\begin{array}{l}\text { Percent- } \\
77 \mathrm{AB} \\
82 \mathrm{~A} \\
86 \mathrm{~A} \\
62 \mathrm{AB} \\
47 \mathrm{~A} \\
36 \mathrm{~B} \\
31 \mathrm{~A} \\
26 \mathrm{AB} \\
21 \mathrm{AB} \\
18 \mathrm{BA} \\
12 \mathrm{~A} \\
8 \mathrm{AB} \\
3 \mathrm{~A}\end{array}$ & $\begin{array}{l}85 \mathrm{~B} \\
89 \mathrm{~A} \\
77 \mathrm{AB} \\
72 \mathrm{~B} \\
61 \mathrm{~B} \\
43 \mathrm{~B} \\
38 \mathrm{~A} \\
31 \mathrm{~B} \\
14 \mathrm{~B} \\
30 \mathrm{~B} \\
16 \mathrm{~A} \\
11 \mathrm{~B} \\
5 \mathrm{~A}\end{array}$ & $\begin{array}{l}78 \mathrm{a}^{3} \\
75 \mathrm{a} \\
75 \mathrm{a} \\
63 \mathrm{~b} \\
46 \mathrm{c} \\
35 \mathrm{~d} \\
31 \mathrm{~d} \\
26 \mathrm{e} \\
21 \mathrm{ef} \\
20 \mathrm{f} \\
16 \mathrm{f} \\
6 \mathrm{~g} \\
5 \mathrm{~g}\end{array}$ \\
\hline Mean & 36 & 34 & 39 & 44 & 38 \\
\hline
\end{tabular}

IResuits are based on 568 returned questionnaires.

2 Percentages in the same row followed by the same upper case letter are not significantly different.

${ }^{3}$ Percentages followed by the same lower case letter are not significantly different.

Pasture refers to a seeding of introduced plants and, in this paper, is distinct from range.

ranch sizes in terms of investment in range improvement practices, and the rancher's perceived needs for range improvement research were tested statistically by the chi-square test. The probability level was set at $5 \%(0.05)$ for all tests.

\section{Results and Discussion}

Ranchers returned 568 of the 1,253 questionnaires (a $45 \%$ response rate). Sixty-eight percent of those who returned the questionnaire requested results from the survey, and $32 \%$ consented to participate in personal interviews. There were no significant differences among the ranch size categories with respect to response to the survey, interest in the survey results, or consent to be interviewed.

\section{Rancher Selection of Range Improvement Practices}

Thirteen range improvement practices were listed in the questionnaire and ranchers were asked to indicate practices in which they had invested money during the last 5 years. Over $75 \%$ of those who returned the questionnaire had invested money in new equipment, water facilities, or improved breeding stock during the 5-year period (Table 1). Sixty-three percent had invested in additional fencing.

Table 2. Kinds of improvements and number of ha per range improvement unit on three ranch sizes in southeastern Montana.'

\begin{tabular}{|c|c|c|c|c|}
\hline \multirow[b]{3}{*}{ Kind of improvement } & \multirow{3}{*}{$\begin{array}{l}\text { Improve- } \\
\text { ment unit }\end{array}$} & \multicolumn{3}{|c|}{ Ranch size } \\
\hline & & Small & Medium & Large \\
\hline & & $50-200 \mathrm{AU}$ & $20 \overline{-400 \mathrm{AU}}$ & $>\overline{400 \mathrm{AU}}$ \\
\hline & \multicolumn{4}{|c|}{ Number of hectares per improvement unit ${ }^{2}$} \\
\hline $\begin{array}{l}\text { Water developments } \\
\text { (wells, springs, and } \\
\text { reservoirs) }\end{array}$ & each & $\begin{array}{c}270 \\
(291)\end{array}$ & $\begin{array}{c}226 \\
(113)\end{array}$ & $\begin{array}{c}3,73 \\
(282)\end{array}$ \\
\hline Fence & one $\mathbf{k m}$ & $\begin{array}{c}42 \\
(16)\end{array}$ & $\begin{array}{c}62 \\
(19)\end{array}$ & $\begin{array}{l}81 \\
(35)\end{array}$ \\
\hline Hayland & one ha & $\begin{array}{c}22 \\
(14)\end{array}$ & $\begin{array}{l}53 \\
(49)\end{array}$ & $\begin{array}{c}75 \\
(64)\end{array}$ \\
\hline
\end{tabular}

Data based on information collected during personal interviews with 69 ranchers in southeastern Montana, July-Scptember 1980 .

2 Mean standard deviations are in parentheses.
Expenditures for fencing and water development are logical investments. They permit better livestock distribution, save labor, permit easier herd management, and also yield a high rate of return because they allow the rancher to increase livestock carrying capacity (Gray et al. 1965).

The time factor is critical when ranchers are forced to wait long periods for a return on their investment. Projects with relatively short lives and heavy use patterns will generally yield higher net benefits thail do projects with longer lives, and lower levels of use (Godfrey et al. 1979). Thus, ranchers prefer improvements that yield immediate returns. The added expense of waiting for a return may explain why only 46 and $31 \%$ of the ranchers invested in hayland and seeded pastures, respectively.

A much smaller number of ranchers fertilized pasture, fertilized range, and did some contour furrowing $(16,5$, and $6 \%$, respectively). Ranchers may have been reluctant to invest in these practices because they felt that the economic benefits had not been clearly demonstrated or that the practices were uneconomical. The number of investments in contour furrowing could also be limited by the number of acres that are physically adapted to the practice, and because some ranchers believed that furrows made it difficult to work livestock (Lacey et al. 1981).

In contrast, investments to improve breeding stock or equipment were more popular (Table 1). It is difficult to question the wisdom that recognizes the contribution of good livestock to ranch income. Timely investments in machinery are often beneficial for tax purposes. Ranchers also need machinery to replace a labor resource that has been hired into other industries (Gray 1968).

\section{Relationship between Ranch Size and Range Improvements}

Each of the 4 ranch size categories followed the same general trend of investing more frequently in structural than in nonstructural improvements. However, the smaller ranches tended to invest less frequently in most of the practices. This investment pattern may be influenced by diminishing returns and economies of size.

Diminishing returns are observed when a variable input (such as an improvment practice) is added to a fixed input (land). Although the total benefit may initially increase at an increasing rate, it soon slows to a decreasing rate and eventually decreases. Small ranches tended to have more fences ( $\mathrm{km}$ ) and hayland (ha) per unit area of land than did the larger sized ranches (Table 2). Although the data suggested that the medium sized ranches had the most water devel- 
opments, many of their developments were reservoirs. In terms of permanent water (springs and wells), the small ranches were developed more intensively.

The different levels of range improvement practices existing between the ranch sizes are believed to influence investment in additional improvements. For example, the average small, medium, and large ranches had 1 ha of hayland, respectively, for every 22 , 53 , and 75 ha of rangeland in their total operation (Table 2). Thus, the operator of the small ranch harvested 1.6 tonnes of hay and straw per AU, while the medium and large ranches harvested $\mathbf{1 . 2}$ and .9 tonnes per $A U$, respectively. Because the relative returns from additional investment in hayland would be less for the smaller ranches, it seems rational that only $40 \%$ of the small ranches developed additonal hayland, in contrast to $61 \%$ of the large ranches (Table 1).

Costs per animal unit tended to decrease as ranch size increased (Table 3). By assuming that ranch size does not influence the

Table 3. Average interest and variable cost per $\mathrm{AU}$ for three ranch sizes in southeastern Montana.1

\begin{tabular}{|c|c|c|c|}
\hline \multirow[b]{3}{*}{ Item } & \multicolumn{3}{|c|}{ Ranch size } \\
\hline & Small & Medium & Large \\
\hline & $50-200 \mathrm{AU}$ & $20 \mathrm{I}-400 \mathrm{AU}$ & $>400 \mathrm{AU}$ \\
\hline $\begin{array}{l}\text { Interest/ } \mathrm{AU}^{2} \\
\text { Variable Cost/ } \mathrm{AU}^{3}\end{array}$ & $\begin{array}{r}\$ 71.56 \\
165.00\end{array}$ & $\begin{array}{r}\$ 37.86 \\
156.00\end{array}$ & $\begin{array}{r}\$ 33.60 \\
138.00\end{array}$ \\
\hline
\end{tabular}

'Data collected during personal interviews with 69 ranchers in southeastern Montana Includes interest on operating, personal property, and real estate loans. Differences are not statistically significant.

${ }^{3}$ Includes interest on operating loan. Does not include interest on personal property and real estate loans or on bull purchases. Differences are not statistically significant.

number of cull brood stock and offspring produced from a given number of animal units, it is reasoned that the cost per animal unit may be used to approximate the cost per unit of output. Because the large ranches pay $\$ 38$ less interest per animal unit, they seem to benefit from economies of size. Thus, large ranches may have more resources a vailable to spend for improvements. This line of reasoning is consistent with Gray (1968), who wrote that the small rancher can seldom afford to make range improvements when needed because of inadequate financial reserves.

The lower cost per animal unit may be one reason why a higher percentage of the large size ranches, rather than the smaller sized ranches, purchased additional rangeland during the last five years (Table 1). This same reasoning may also explain why a higher percent of the medium and large ranches were able to lease additional range.

\section{Rancher Interest in Range Improvement Related Research}

Ranchers receiving questionnaires were asked to list the kinds of range studies that they would like to see conducted in eastern Montana. Only 228 of the returned questionnaires (39\% of the total response) contained research recommendations. Less than $1 \%$ of the respondents indicated that no additional range research was needed. The needs of the remaining $60 \%$ of the respondents are not known.
The ranchers in northeastern Montana were the most reluctant to recommend a topic for research (Table 4). Their lower degree of interest in range research is logical, because northeastern Montana is more farming oriented. The trend of more research recommendations being forwarded from large operations in southeastern Montana may suggest that operators of large ranches are more interested in range improvements. This increased interest may be related to their greater opportunity and ability to invest in the improvement practices. There was no evidence to indicate that a larger percent of the small ranchers were actually "part time" operators.

Most of the perceived research needs could be categorized as "applied" rather than "basic." Although rancher response included nearly every problem area that faces the livestock producer on western ranges, their perceived needs were categorized into 14 groups (Table 5).

Participating ranchers indicated that seeding was the priority range improvement practice needing additional study. Specific seeding needs centered on the development of better forage species (native and tame, cool- and warm-season, irrigated and dryland, and grass and legume). Mechanical treatments (pitting, ripping, chiseling, contour furrowing, and disking) were another suggested area for research (Table 5). Weed control, especially Canada thistle (Cirsium arvense) and leafy spurge (Euphorbia esula) and poisonous plant problems were included in the noxious plant category.

The ranchers' perceived need for studies in a specific area is relatively independent of ranch size (Table 5). However, the large size ranchers did express more interest in grazing system studies. The usefulness of a specialized grazing system may be limited on a small ranch that is already being intensively managed. For example, the small rancher in eastern Montana may be restricted to a specific use pattern because of physical limitations that require certain pastures to be rested at certain times. This may be necessary because parts of the pasture may be seeded to wheat each year, or it may have physical characteristics that make it a valuable winter pasture.

\section{Management Implications}

All components of the range livestock industry should be concerned about long-term trends in productivity. Wheeler (1970) concluded that "the evidence rather clearly indicates a decline in the productivity of the range livestock sector" in the Northern Great Plains. His conclusion was drawn after observing that calf crop percentage and weaning weight had declined from 1958 through 1967. Furthermore, average stocking rate had increased from 12.4 hectares per $A U$ to 11.2 hectares per $A U$ during the same period. However, his stocking rate estimates were not adjusted to compensate for different levels of crop production among ranches. Wheeler apparently reasoned that the total area of range per $\mathrm{AU}$ was less on a livestock-grain operation than on a straight livestock operation, but that the difference was offset because the cropland operations were located in areas of higher productive potential. Regardless of the difficulty in comparing the earlier study to the 1979 data, Wheeler's conclusions have serious implications and a general discussion is merited.

Table 4. Number of returned questionnaires and percent that did not contain a research recommendation by ranch size and location.

\begin{tabular}{|c|c|c|c|c|c|}
\hline \multirow[b]{3}{*}{ Item } & \multicolumn{4}{|c|}{ Ranch size and location } & \multirow[b]{3}{*}{ Total } \\
\hline & \multirow{2}{*}{$\begin{array}{c}\text { North } \\
\text { Small } \\
\text { 50-150 AU }\end{array}$} & \multicolumn{3}{|c|}{ South } & \\
\hline & & $\begin{array}{c}\text { Small } \\
50-200 \mathrm{AU}\end{array}$ & $\begin{array}{c}\text { Medium } \\
201-400 \mathrm{AU}\end{array}$ & $\begin{array}{c}\text { Large } \\
>400 \mathrm{AU}\end{array}$ & \\
\hline Number & 207 & 161 & 99 & 101 & 568 \\
\hline $\begin{array}{l}\text { Percent with no } \\
\text { recommendation } 1\end{array}$ & $67 a$ & $59 \mathrm{ab}$ & $57 a b$ & $50 \mathrm{~b}$ & \\
\hline
\end{tabular}

'Percentages followed by the same lower case letter are not significantly different. 
Table 5. Percent of eastern Montana ranchers indicating range improvement research needs by range improvement category and ranch size.'

\begin{tabular}{|c|c|c|c|c|c|}
\hline \multirow[b]{3}{*}{ General topic } & \multicolumn{4}{|c|}{ Ranch size and location } & \multirow[b]{3}{*}{$\begin{array}{c}\text { Total } \\
\text { sample }\end{array}$} \\
\hline & \multirow{2}{*}{$\begin{array}{c}\text { North } \\
\text { Small } \\
50-150 \mathrm{AU}\end{array}$} & \multicolumn{3}{|c|}{ South } & \\
\hline & & $\begin{array}{c}\text { Small } \\
50-200 \mathrm{AU}\end{array}$ & $\begin{array}{c}\text { Medium } \\
201-400 \mathrm{AU}\end{array}$ & $\begin{array}{c}\text { Large } \\
>400 \mathrm{AU}\end{array}$ & \\
\hline Seeding & $11 A^{2}$ & $12 \mathrm{~A}$ & $10 \mathrm{~A}$ & $16 \mathrm{~A}$ & $12 a^{3}$ \\
\hline Mechanical & $7 \mathrm{~A}$ & $8 \mathrm{~A}$ & $3 A$ & $10 \mathrm{~A}$ & $7 \mathrm{~b}$ \\
\hline Fertilization & $7 \mathrm{~A}$ & $5 \mathrm{~A}$ & $5 \mathrm{~A}$ & $10 \mathrm{~A}$ & $7 b$ \\
\hline Noxious plants & $4 \mathrm{~A}$ & $6 \mathrm{~A}$ & $6 \Lambda$ & $4 \mathrm{~A}$ & $5 \mathrm{bc}$ \\
\hline Sagebrush control & $1 \mathrm{~A}$ & $5 \mathrm{~A}$ & $\mathbf{3 A}$ & $3 \mathbf{A}$ & $3 \mathrm{~cd}$ \\
\hline Economic & $3 \mathrm{~A}$ & $3 \mathbf{A}$ & $2 \mathrm{~A}$ & $2 \mathrm{~A}$ & $3 \mathrm{~cd}$ \\
\hline Grazing systems & IA & IA & $3 \mathrm{AB}$ & $8 B$ & $3 \mathrm{~cd}$ \\
\hline Irrigation & $2 \mathrm{~A}$ & $3 \mathrm{~A}$ & $0 \mathrm{~A}$ & $4 A$ & $2 d$ \\
\hline Livestock & $2 \mathrm{~A}$ & IA & $2 \mathrm{~A}$ & $4 A$ & $2 \mathrm{~d}$ \\
\hline Predator & $1 \mathrm{~A}$ & $\mathbf{0 A}$ & $2 \mathrm{~A}$ & $2 \mathrm{~A}$ & ld \\
\hline Grasshopper & $\mathbf{0 A}$ & $1 \mathrm{~A}$ & IA & $5 \mathrm{~A}$ & ld \\
\hline Rain & $2 \mathrm{~A}$ & $2 \mathrm{~A}$ & IA & $\mathbf{0 A}$ & ld \\
\hline Other & 12 & 8 & 12 & 10 & 11 \\
\hline Mean & 3.8 & 4.1 & 3.9 & 5.8 & 4.3 \\
\hline
\end{tabular}

'Results are based on 568 questionnaires returned by mail.

2Percentages in the same row followed by the same upper case letter are not significantly different.

JPercentage followed by the same lower case letter are not significantly different.

Average calf crop percentage was $86 \%$ and weaning weight of steer calves was $201 \mathrm{~kg}$ on the 69 ranches in 1979. The differences between ranch sizes were not significant. Although the 1979 estimates appear to be higher than the $82 \%$ calf crop and the $191 \mathrm{~kg}$ weaning weight that Wheeler (1970) reported in 1967 , there is no evidence that range condition has improved. Instead, the production data may reflect variations in weather (Newbauer et al. 1980, Branson and Miller 1981), genetic improvement, and/or better animal husbandry.

Average stocking rate (total ha in operation divided by total number of AU's) had decreased from 11.2 ha per AU in 1967 to 12.6 ha per AU in 1979. This apparent decrease in stocking rate is somewhat surprising because the favorable precipitation in southeastern Montana had caused the forage yield of some species to double during the 1967-77 period (Newbauer et al. 1980). Rather than a conscious conservation goal by the ranchers, the reduced stocking rate may be a reflection of the cattle cycle. The total number of cattle and calves in Montana was higher in 1967 $(2,869,000$ head) (U.S. Dept. of Agr. 1968) than in $1979(2,607,000$ head) (U.S. Dept. of Agr. 1980). This 9\% decrease in cattle numbers between 1967 and 1979 approximates the stocking rate reduction.
There was no measurable difference in the 1979 stocking rate between the 3 ranch sizes when the total land base in each operation was divided by the total number of AU's carried yearlong (Table 6). However, small ranchers fed 1.6 tonnes of hay and straw per $A U$, while large and medium sized ranches fed 1.2 and 0.9 tonnes, respectively. When this feeding program is considered along with the number of hectares of crop and hayland, the actual stocking rate on rangeland is reduced to about 17 ha/ AU (Table 6). Although stocking rates on range did not vary significantly between ranch sizes, $43 \%$ of the large sized ranches compared to only $5 \%$ of the small sized ranches purchased additional hay. Largely because of the extra hay, expenditures on supplemental feed per AU averaged \$17 higher for large sized ranches. The costs of purchased hay were not included in (Table 6). It is not known how much of the difference in supplemental feed costs between ranch sizes can be attributed to the usage of range improvement practices.

Simple stocking rate comparisons between ranch sizes are also confounded by breed differences. Eighty-nine percent of the small ranches used the traditional British cattle breeds (Hereford, Angus, or a Hereford-Angus cross). In contrast, only $75 \%$ and $59 \%$ of the medium and large ranches, respectively, restricted their

Table 6. Mean and standard deviation of number of AU's, range and non-range hectarage, amount of hay and straw normally fed, and two stocking rate estimates for three ranch sizes in southeastern Montana, 1979.1

Average ranch unit

\begin{tabular}{|c|c|c|c|c|c|c|c|c|c|c|}
\hline \multirow[b]{4}{*}{ Range size } & \multirow[b]{4}{*}{$\begin{array}{l}\text { Total } \\
\text { AU's }\end{array}$} & & & & & & & & & \\
\hline & & \multirow{3}{*}{$\begin{array}{l}\text { Total } \\
\text { land } \\
\text { (ha) }\end{array}$} & \multirow{3}{*}{$\begin{array}{c}\text { Stocking } \\
\text { rate } \\
\text { (Total ha/ } / \wedge U)\end{array}$} & \multirow{2}{*}{\multicolumn{2}{|c|}{ Land }} & \multicolumn{3}{|c|}{ Hay fed } & \multicolumn{2}{|c|}{ Rangeland hectarage } \\
\hline & & & & & & \multirow{2}{*}{\multicolumn{2}{|c|}{$\begin{array}{l}\text { Grass and } \\
\text { alfalfa straw } \\
\text { tonnes }\end{array}$}} & \multirow{3}{*}{$\begin{array}{c}\begin{array}{c}\text { AU's } \\
\text { Equivalents }\end{array} \\
\begin{array}{c}56 \\
(24)\end{array}\end{array}$} & \multirow{3}{*}{$\begin{array}{c}\text { AU's } \\
82 \\
(28)\end{array}$} & \multirow{2}{*}{$\begin{array}{l}\text { Stocking } \\
\text { rate } \\
\text { (ha/AU) }\end{array}$} \\
\hline & & & & $\begin{array}{r}\text { Non-range } \\
\text { ha }\end{array}$ & Range & & & & & \\
\hline $\begin{array}{l}\text { Small } \\
\qquad(50-200 \mathrm{AU})\end{array}$ & $\begin{array}{l}138 \\
(38)^{3}\end{array}$ & $\begin{array}{l}1579 \\
(601)\end{array}$ & $\begin{array}{l}11.6^{4} \\
(3.7)\end{array}$ & $\begin{array}{c}168 \\
(120)\end{array}$ & $\begin{array}{l}1412 \\
(589)\end{array}$ & $\begin{array}{l}198 \\
(86)\end{array}$ & $\begin{array}{c}18 \\
(35)\end{array}$ & & & $\begin{array}{l}18.3 \\
(7.8)\end{array}$ \\
\hline $\begin{array}{l}\text { Medium } \\
\quad(201-400 \mathrm{AU})\end{array}$ & $\begin{array}{l}294 \\
(60)\end{array}$ & $\begin{array}{c}3841 \\
(2410)\end{array}$ & $\begin{array}{l}12.9 \\
(4.2)\end{array}$ & $\begin{array}{c}297 \\
(350)\end{array}$ & $\begin{array}{c}3544 \\
(1599)\end{array}$ & $\begin{array}{c}325 \\
(184)\end{array}$ & $\begin{array}{c}29 \\
(52)\end{array}$ & $\begin{array}{c}92 \\
(51)\end{array}$ & $\begin{array}{l}202 \\
(53)\end{array}$ & $\begin{array}{l}17.6 \\
(6.1)\end{array}$ \\
\hline $\begin{array}{l}\text { Large } \\
(>400 \mathrm{AU})\end{array}$ & $\begin{array}{r}733 \\
(326)\end{array}$ & $\begin{array}{l}10083 \\
(9330)\end{array}$ & $\begin{array}{l}13.5 \\
(4.9)\end{array}$ & $\begin{array}{c}527 \\
(453)\end{array}$ & $\begin{array}{c}9556 \\
(5880)\end{array}$ & $\begin{array}{c}562 \\
(343)\end{array}$ & $\begin{array}{c}64 \\
(116)\end{array}$ & $\begin{array}{l}160 \\
(96)\end{array}$ & $\begin{array}{c}573 \\
(289)\end{array}$ & $\begin{array}{l}16.4 \\
(5.6)\end{array}$ \\
\hline
\end{tabular}

Data collected during personal interviews with 69 ranchers.

${ }^{2} \mathrm{Hay}$ and straw converted to AUM's at 3.3 and 1.1 per tonne, respectively.

${ }^{3}$ Standard deviations of the means are in parentheses.
4 Mean stocking rate values may vary slightly from those calculated using total AU's and total land due to rounding errors. 


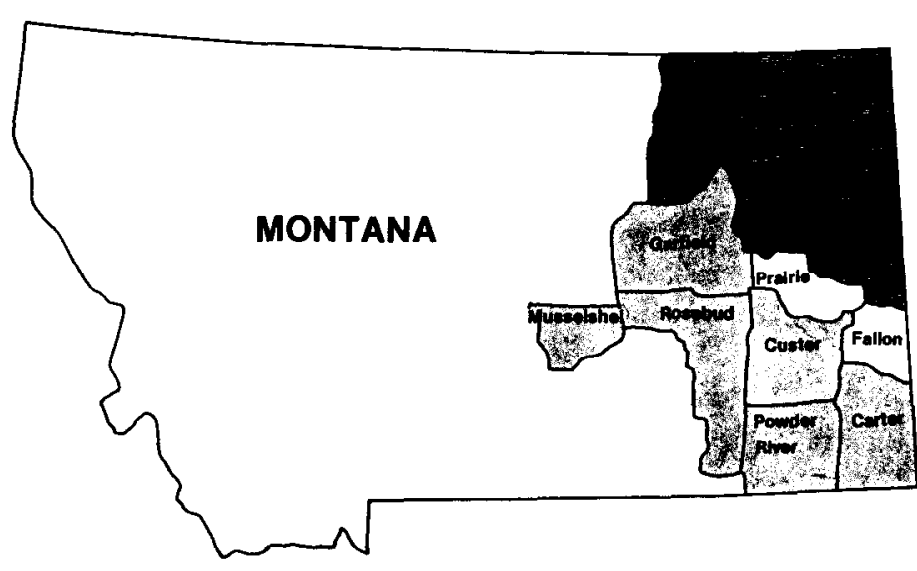

Fig. 1. Map of eastern Montana showing eight northeastern and six southeastern counties that were included in the study area (Prairie and Fallon were omitted from the study).

operations to these breeds. This suggests that a higher percentage of large ranches are using larger European breeds (Charolois, Simmental, Limousin, Maine-Anjou, etc.) or large breed crosses. Because larger animals require more feed, the number of AU's carried on the medium and large sized ranches is probably underestimated.

\section{Conclusions}

Results of this study indicate that about $75 \%$ of the ranches had invested in one or more structural types of range improvements during the last 5 years. A much lower percentage had invested in one or more nonstructural improvements. In general, large ranches invested in improvements more frequently than did small ranches.

One reason for the investment differences among ranch sizes is the tendency for large ranches to have fewer range improvements per unit area than do smaller ranches. Thus, additional improvements may earn higher relative returns on the large ranches. This appears logical because as increasing amounts of a variable input (improvement practice) are added to a ranching operation, all other inputs held constant, the amount of output yielded per unit of variable input will eventually decrease.

Although production levels between ranch sizes were not statistically different, large ranches appeared to be a little more efficient in the sense that their variable costs per animal unit were generally lower. It is possible that they may be diverting their savings from the reduced costs into range improvements. Lower costs would also improve their cash flow statement and may make it easier for them to obtain loans for range improvement practices. Thus, availability of financing may also explain different investment behavior among ranch sizes.

Data indicated that land (cropland and rangeland, combined) on small ranches was used more intensively than land on large ranches. Not only did small ranches have more range improvements per unit area, but their overall management program also included a larger hay base that allowed a longer winter feeding period. After differences in supplemental feeding were accounted for, each of the 3 ranch sizes were found to stock their range at about 1.5 ha per AUM. However, supplemental feeding costs per AU were higher on large sized ranches. This may suggest that large ranches could intensify their management practices and eventually increase the average rate at which they are stocked, or reduce their supplemental feeding costs.

Sampled ranchers indicated that seeding was the priority range improvement topic that needed additional study. However, their perceived needs included a wide range of problems, mostly of the applied nature. Although ranchers provide important guidance for research efforts in the area of range improvements, it would be impractical to conduct a research program in each of their individual problem areas. Instead, it seems that ranchers must be consulted, and a balanced program containing both applied and basic research be formulated. This process would ensure that range research programs are as productive as possible.

\section{Literature Cited}

Black, A.L., and L.L. Reitz. 1969. Row spacing and fertilization influences on forage and seed yields of intermediate wheatgrass, Russian wild rye, and green needlegrass on dryland. Agron. J. 61:801-805.

Branson, F.A., and R.F. Miller. 1981. Effects of increased precipitation and grazing management on northeastern Montana rangelands. J. Range Manage. 34:3-10.

Cook, C.W., and N. Jefferies. 1963. Better distribution of cattle on mountain ranges. Utah Sci. 24:48-49.

Godfrey, B., L. Sharp, and E. Sellasie. 1979. The economic returns from seeding an area to crested wheatgrass. Idaho Agr. Exp. Sta. Bull. No. 588.

Gray, J.R. 1968. Ranch Economics. lowa State Univ. Press, Ames.

Gray, J.R., T.M. Stubblefield, and N.K. Roberts. 1965. Economic aspects of range improvements in the Southwest. New Mexico Agr. Exp. Sta. Bull. 498.

Horvath, J.C., D.I. Schweitzer, and E.F. Bell. 1978. Grazing on National Forest systems lands: Costs of increasing capacity in the northern region. USDA Forest Serv. Intmtn. Forest and Range Exp. Sta. Res. Pap. INT-215.

Houston, W.R. 1971. Range improvement methods and environmental influences in the northern Great Plains. USDA, Agr. Res. Serv. In cooperation with Montana Exp. Sta. Production Res. Rep. No. 130.

Houston, W.R., and J.J. Urick. 1972. Improved spring pastures, cow-calf production, and stocking rate carry over in northern Great Plains. U.S. Dep. Agr., Agr. Res. Serv., in cooperation with Montana Agr. Exp. Sta. Tech. Bull. No. 1451.

Kearl, W.G. 1975. Economic and management constraints for livestock production arid shrublands. p. 116-124. In: Arid Shrublands, Proc. of the Third Workshop of the United States/Australia Rangelands Panel, Tucson, Ariz., April 4, 1973.

Kearl, W.G. 1979. Economics of range reseeding. Wyoming Agr. Ext. Serv. AE 79-01R.

Lacey, J.R. 1981. Economic evaluation of ranch efficiency and range improvement practices in eastern Montana. Ph.D. Diss., Utah State Univ., Logan

Lacey, J.R., J.E. Mowbray, and J.R. Wight. 1981. Ranches evaluate contour furrows for livestock grazing. Rangelands. 3:58-60.

Montana Department of Agriculture. 1980. Montana Agricultural Statistics, Vol. XVHII. Compiled by Montana Crop and Livestock Reporting Serv. In cooperation with USDA, Econ., Stat., and Coop. Serv., Federal Blg. and U.S. Courthouse, Helena, Mont.

Newbauer, J.J., III, L.M. White, R.M. Moy, and D.A. Perry. 1980. Effects of increased rainfall on native forage production in eastern Montana. $J$. Range Manage. 33:246-250.

Snedecor, G.W., and W.G. Cochran. 1967. Statistical methods. 6th. Ed. lowa State Univ. Press, Ames.

U.S. Department of Agriculture. 1968. Agriculture Statistics. 1968. U.S. Gov. Printing Office, Washington, D.C.

U.S. Department of Agriculture. 1980. Agriculture Statistic. 1980. U.S. Gov. Printing Office, Washington, D.C.

Vallentine, J.F. 1971. Range Developments and Improvements. Brigham Young Univ. Press, Provo, Utah.

Wheeler, R.O. 1970. The range cattle industry of the northern Great Plains-A comparison of production rates between 1958 and 1967. Montana Agr. Exp. Sta. Bull. 643. Montana State Univ., Bozeman.

Wight, J.R. 1975. A summary of range fertilization research conducted by the Northern Plains Soil and Water Research Center. In: Proc. of the Range Fertilizer Symp., Havre, Mont., July 1974. Montana Agr. Exp. Sta. Res. Rep. 70.

Wight, J.R., F.H. Siddoway, R.J. Kartchner, and J.L. Bishop. 1978. Contour furrows seeded with grasses and legumes increase production on semiarid range sites. p. 643-644. In: D. N. Hyder (Ed.) Proc. Ist Int. Rangeland Congr., Denver, Colo. 1978.

Wight, J.R., and L.M. White. 1974. Interseeding and pitting on a sandy range site in eastcrn Montana. J. Range Manage. 27:206-210.

Workman, J.P., and J.F. Hooper. 1968. Preliminary economic evaluation of cattle distribution practices on mountain rangelands. J. Range Manage. 21:301-304. 